\title{
GROWTH PERFORMANCE, SOME RUMEN PARAMETERS AND BLOOD PROFILE OF MALE ZARAIBI GOATS FED DIETS CONTAINING SESBANIA SESBAN SEEDS AS A NEW SOURCE OF PROTEIN.
}

El-Kholany, M. E., E. S. Soliman, F. A. El-Sayed, and M. E. Ahmed. Animal Production Research Institute, Agriculture Research Center, Dokki, Giza, Egypt.

\begin{abstract}
This work carried to investigate the effect of using Sesbania sesban seeds (SS) in goat's diets on nutrients digestibility, some rumen parameters and growth performance Zaraibi kids. Twenty Zaraibi kids ( average $16.0 \mathrm{~kg}$ live weight and 4 to 5 months old) were divided into 4 groups (5 kids each). The control group $\left(G_{1}\right)$ was fed a ration consisting of concentrate feed mixture and corn silage according to NRC (1981) recommendation. Sesbania sesban seeds was used to replace 10,20 and $30 \%$ of concentrate's protein for groups $\mathrm{G}_{2}, \mathrm{G}_{3}$ and $\mathrm{G}_{4}$, respectively. The feeding trails lasted 14 weeks. In addition, three male Zaraibi goats of each group were involved in digestion trail to evaluate the feeding value of the tested diets.

The obtained results showed that the daily feed intake tended to decrease $\left(71.31,69.74,68.27\right.$ and $\left.66.99 \mathrm{~g} / \mathrm{kg}^{0.75}\right)$ as a result to substitution of concentrate feed mixture ( CFM) with Sesbania seeds (SS) in goat's rations $\left(G_{1}, G_{2}, G_{3}\right.$ and $G_{4}$, respectively). In the sametime, the daily water consumption as $\mathrm{ml} / \mathrm{g}$ DM intake was slightly higher with increasing Sesbania seeds in the rations.

As regard to ruminal parameters, the effect of the tested experimental rations on ruminal $\mathrm{pH}$ values and ammonia- $\mathrm{N}$ concentration were not significant. But, ruminal total VFA's and microbial protein content during 3 and 6 hrs post-feeding were significantly higher $(P<0.05)$ with $G_{2}$ compared with $\mathrm{G}_{4}$. Similarly, molar proportion of ruminal VFA's showed higher acetate and propionate but lower butyrate with $\mathrm{G}_{2}$ than other groups. The obtained results indicated also that most tested blood parameters were not significantly affected by tested rations.

The digestion coefficients of most nutrients (DM, OM, CF, NFE and EE) and feeding values ( TDN and DCP) were not significantly affected by the tested rations. However, the highest values of digestibility of all nutrients and feeding values were recorded with $\mathrm{G}_{2}$.

Daily body gain recorded the highest value ( $77.16 \mathrm{~g}$ ) with $\mathrm{G}_{2}$ followed by $\mathrm{G}_{1}(75.72 \mathrm{~g})$ then $\mathrm{G}_{3}(74.50 \mathrm{~g})$ and lastly $\mathrm{G}_{4}(71.82 \mathrm{~g})$ and the differences were not significant. The feed conversion efficiency, based on DM and DCP, was better ( 8.51 and 0.77 , respectively ) with $\mathrm{G}_{2}$ in comparison with the other groups. Moreover, the values of feed conversion as TDN were also better with the three tested rations ( $5.81,5.77$ and 5.82 for $\mathrm{G}_{2}, \mathrm{G} 3$ and $\mathrm{G}_{4}$, respectively) than with control ( 5.97 ). Moreover, the economic efficiency was noticeably higher $(1.86,2.02,2.09$ and $2.17 \%)$ with increasing Sesbania
\end{abstract}


seeds levels $(0,10,20$ and $30 \%)$ in the goats rations $\left(G_{1}, G_{2}, G_{3}\right.$ and $G_{4}$, respectively). Accordingly, Sesbania sesban seeds could be used as a source of protein for feed, to replace up to $30 \%$ of CFM protein in goats rations since it did not have negative effect on feeding value and growth performance.

Keywords: Sesbania seeds- Zaraibi kids- growth performance- feeding value- fermentation in the rumen - economic efficiency.

\section{INTRODUCTION}

Nutrition is a major factor affecting the physiological and metabolic status of from animals. In Egypt, there is a wide gap between the available feedstuffs and farm animals requirements. During summer season, green forages with reasonable protein contents are not adequately available. Accordingly, there is a clear drop in productive performance. Many attempts were carried out to introduce some green forages or seeds containing higher protein content such as Sesbania sesban and Erythrin indica ( Soliman et al., 1997 and Pugalenthi et al. 2004).

Legume seeds are valuable sources of protein, oil, carbohydrates, minerals and vitamins. They are playing an important role in human nutrition mainly in developing countries (Mohamed and Rangappa, 1992 and Yanez et al., 1995).

Sesbania (Sesbania sesban) is a legume shurb adapted to summer season and plants can be cultivated successfully by seeds under irrigation ( Abdl-Rahman et al., 1995). In study by Hossain and Becker (2001) on four different sesbania seeds as S. aculeata, S. rostrata, S. sesban ( accession $10865 \mathrm{D}$ ) and S. sesban (accession $15019 \mathrm{D}$ ), the obtained data indicated that the crude protein content in different seeds ranged from 29.1 to $33.1 \%$, crude lipid $4.7-6.0 \%$, crude fiber $10.9-15.8 \%$, total crude carbohydrates $44.6-47.4 \%$ and gross energy $19.2-20.0 \mathrm{k} \mathrm{j} / \mathrm{g}$. They found also that palmtic, stearic, oleic, linoleic, and linolenic acids were the major fatty acids ( FA's) and the total unsaturated and essential FA's ranged from 78.1 to 82.3 $\%$ and 77.2 to $80.3 \%$, respectively.

Pugalenthi et al. (2004) reported that both crude protein and lipid contents in Sesbania seeds are higher ( 31.08 and 6.23, respectively) when compared with Erythrina indica seeds ( 21.45 and $2.24 \%$, respectively), but some essential amino acids such as cysteine, methionine and threonine in both seeds were found to be deficient when compared with FAO / WHO ( 1991) requirement pattern.

In recent study, Arekemase et al. (2013) studied the quantitative evaluation of the nutritional constituents of Sesbania sesban seeds such as protein, energy, minerals and vitamins and they found that Sesbania seeds were rich in all the essential nutrients needed by the live stocks.

Literature on using Sesbania sesban seeds (SS) in feeding Zaraibi goats is scarce. Therefore, the aim of this work was to investigate the effect of feeding Sesbania seeds as a new source of protein to partly replace the expensive $\mathrm{CP}$ of the concentrate feed mixture on digestion coefficients, feeding values 
and growth performance. Some metabolic parameters ( rumen and blood) were also studied.

\section{MATERIALS AND METHODS}

This study was conducted at the Animal Production Research Station, El-Serw, belonging to Animal Production Research Institute, Agricultural Research Center, Egypt.

\section{Animals and feeding :}

Twenty growing Zaraibi kids, selected from El-Serw Station Herd, with an average age of 5 to 6 months and $16.0 \pm 0.20 \mathrm{~kg}$ weight were used. The animals were divided according to their body weight into 4 similar groups (5 each) to study the effect of using sesbania seeds (SS) as a source of protein in goat's diets at levels, of 0.0 (group1), 10\% (group2), 20\% ( group3) and 30\% ( group4) from CFM protein. Each group was housed in a semi-roofed yard ( $4 \times 3 \times 5$ meters). The animals were weighed at the beginning then biweekly. Zaraibi kids were fed for 2 weeks as a transitional period on the experimental rations before the start of the experimental work. Feeding the experimental rations lasted 14 weeks. Three digestibility trials were conducted using 9 male Zaraibi goats ( 3 each) to evaluate the feeding values of the tested diets. The nutrient requirements were calculated according to NRC (1981) of goats. The amounts of concentrate feed mixture and corn silage were estimated to cover 70 and $30 \%$ of crude protein requirements, respectively. Thus, the concentrate (CFM) and roughage (corn silage) were offered at 60:40 ratio as reported by Tawfik et al. (2005) and Soliman et al. (2010) on growing lambs and Zaraibi kids, respectively. Animals were fed the assigned ingredients as mixed rations. The CFM consisted of $26 \%$ undecortecated cotton meal, $40 \%$ yellow corn, $27 \%$ wheat bran, $3.5 \%$ molasses, $2 \%$ limestone, $1 \%$ common salt and $0.5 \%$ minerals mixture. The chemical composition of the tested ingredients was determined (Table 1). Water was available at all times and was measured as average for each group ( per $\mathrm{ml} / \mathrm{h} / \mathrm{l})$. Diets were offered twice daily at $8.0 \mathrm{am}$ and $3.0 \mathrm{pm}$ any refused were daily recorded. Proximate chemical analysis of the feeds and feces was carried out according to A.O.A.C. (1995).

\section{Rumen samples:}

Rumen fluid samples were taken from 3 animals of each experimental group using stomach tube before feeding ( 0 time) and at 3 and $6 \mathrm{hrs}$ post-feeding at the end of growing period. The samples were filtered through 3 layers of gauze and immediately subjected to the determination of $\mathrm{pH}$ value by $\mathrm{pH}$ meter. Ammonia nitrogen $\left(\mathrm{NH}_{3}-\mathrm{N}\right)$ concentration was measured according to the method of Conway (1957), Microbial protein was determined according to Schultz and Schultz (1970), whereas total volatile fatty acids (VFA's) was determined according to the technique described by Warner (1964).

\section{Blood samples:}

Blood samples were collected from the jugular vein once before feeding ( 3 animals in each) at the end of growing period. Blood samples were 
centrifuged at $4000 \mathrm{rpm}$ for $20 \mathrm{~min}$. Part of the separated serum was directed to enzymes activity determination, while the other part was stored frozen at$20^{\circ} \mathrm{C}$ till the biochemical analysis. Commercial kits were used for colorimetric biochemical determinations.

Economic efficiency :

Economic efficiency was calculated as total output/ total input according to the local prices ( where 1 ton of CFM cost 2300LE, CS cost 300 LE and 1 ton Sesbania seeds coat 1000 LE while $1 \mathrm{~kg}$ live body weight of male Zaraibi goats for 31LE).

Statistical analysis:

Data were statistically analyzed by one-way analysis of variance according to Snedecor and Cochran (1982) and the differences among means were tested using Duncan's Multiple Range Test (Duncan, 1955).

\section{RESULTS AND DISCUSSION}

\section{1- Chemical composition :}

The chemical analysis as shown in Table 1 indicated that Sesbania seeds (SS) contained $31.19 \% \mathrm{CP}, 5.30 \% \mathrm{EE}, 52.63 \% \mathrm{NFE}, 7.31 \% \mathrm{CF}$ and $3.57 \%$ Ash. Similar results were reported by Pugalenthi et al., (2004) who found that Sesbania seeds contained $31.08 \% \mathrm{CP}, 52.61 \mathrm{NFE}, 6.81 \% \mathrm{CF}$, $3.27 \%$ Ash on DM basis, while EE was higher than contained herein ( 6.23 vs. $5.30 \%$ ). However, Hossain and Becker ( 2001) studied the chemical analysis of different Sesbania seeds and found that the crude protein content in different seeds ranged from 29.1 to $33.1 \%$, crude lipid $4.7-6.0 \%$, crude fiber $10.9-15.8 \%$, total crude carbohydrates $44.6-47.4 \%$ and gross energy $19.2-20.0 \mathrm{k} \mathrm{j} / \mathrm{g}$.

\section{2- Daily feed intake and water consumption :}

The average daily DM intake of Zaraibi kids is summarized in Table 2. The total DM intake as $\mathrm{g} / \mathrm{h}$ tended to decrease ( $666,657,637$ and $621 \mathrm{~g}$ ) with increasing level of Sesbania seeds ( $0,10,20$ and 30\%) in goats rations. The corresponding values of intake when related to metabolic body size were $71.31,69.74,68.27$ and $66.99 \mathrm{~g} / \mathrm{kgw}^{0.75}$, respectively. The same trend was observed also with daily intake as \% BW between the experimental treatments as shown in Table 2. This decrease in DM intake with increasing level of Sesbania seeds attributed to the ratio of crude protein in Sesbania seeds was greatly higher than CFM ( 31.19 vs. $14.0 \%$ ) as shown in Table 1. The obtained values of daily DM intake are within the normal range given by Ahmed et al. (2000) for Zaraibi kids fed restricted 100\% high concentrate ( ranged from 623.1 vs. $668.9 \mathrm{~g} / \mathrm{h}$ ). Also, Soliman et al.(1997) observed that the daily DM intake when related to body weight (\% BW) ranged from 2.94 to 3.11 in Zaraibi kids fed CFM + Sesbania sesban forage.

Concerning water consumption, the obtained data indicated that the differences in water consumption as $\mathrm{L} / \mathrm{head}, \mathrm{ml} / \mathrm{kg} \mathrm{BW}$ or $\mathrm{ml} / \mathrm{kgw} 0.75$ among treatments were not noticeable as shown in Table 2. But, the values of water consumption as $\mathrm{ml} / \mathrm{g}$ DM intake was higher (3.11, 3.21, 3.34 and 3.36 ) with increasing level of Sesbania in kid's rations( 0, 10, 20 and $30 \%$, 
respectively). The present estimates of water consumption are nearly similar to those obtained by Ibrahim et al. ( 2012) on growing lambs ( ranged from 196 to $253 \mathrm{ml} / \mathrm{kg} \mathrm{w}^{0.75}$ and from 2.85 to $3.77 \mathrm{ml} / \mathrm{g}$ DM intake ).

\section{3- Ruminal parameters :}

Results of $\mathrm{pH}$ values ( Table, 3) indicated that maximum $\mathrm{pH}$ values were recorded at 0 time with all groups without significant differences among treatments and then gradually decreased to the minimum values at $3 \mathrm{hrs}$ post feeding and tended to increase again thereafter at $6 \mathrm{hrs}$ post feeding with all groups. Similar trend were observed by Zeid et al. (2009) and Ibrahim et al. (2012) with Zaraibi kids and Rahmani lambs, respectively. In the sametime, ruminal ammonia- $\mathrm{N}$ concentration was greatly higher post-feeding than before feeding and that maximum values of $\mathrm{NH}_{3}-\mathrm{N}$ in the rumen were reached at $3 \mathrm{hrs}$ post-feeding then decreased with all groups without noticeable differences among tested experimental treatment. Similar results were observed by Shehata et al. (2006) with using some other wild plants ( reed) in goats rations.

As regard to microbial protein, the obtained results indicated that microbial protein content during 3 and 6 hrs post-feeding was significantly higher $(P<0.05)$ with $\mathrm{G}_{2}$ ( 0.563 and 0.507 , respectively) compared with $\mathrm{G}_{4}$ ( 0.527 and 0.467 , respectively) whereas $\mathrm{G}_{1}$ and $\mathrm{G}_{3}$ recorded medium values as shown in Table 3. Generally, the highest values of microbial protein ( $0.337,0.563$ and 0.507 ) and lowest values of ruminal ammonia-N concentration (16.93, 22.20 and 20.87) were recorded with $\mathrm{G} 2$ at oll times ( 0,3 and 6 hrs, respectively).

Data of ruminal total VFA's concentrations as well as proportions of individual VFA's \% are presented in Table 4. Rumen total VFA's concentrations ( $\mathrm{m} \mathrm{Eq} / 100 \mathrm{ml})$ post-feeding $(3$ and $6 \mathrm{hrs})$ were the highest values with $\mathrm{G}_{2}$ ( 11.70 and 10.57 , respectively), while the lowest value was detected with $G_{4}$ ( 11.13 and 10.13 , respectively) and the differences were significant at two hours. Molar proportion of ruminal VFA's showed higher acetate and propionate but lower butyrate with $\mathrm{G}_{2}$ than other groups as shown in Table 4. The differences between $\mathrm{G}_{2}$ and $\mathrm{G}_{4}$ in both propionate and butyrate were significant. In the sametime, the effect of experimental rations on valeric, isobutyric and isovaleric were not significant ( Table, 4).

Generally, the highest value of total VFA's concentration was at $3 \mathrm{hrs}$ post-feeding which was reflected on lowering $\mathrm{pH}$ values $($ Table,3) at that time as reported by Shehata et al. (2006) and Zeid et al. (2009) with Zaraibi goats.

\section{4- Blood profile :}

Data of hemato-biochemical parameters are presented in Table 5. The results indicated that most tested blood parameters were not significantly affected by the tested experimental rations.

Comparison of hematological parameters revealed small fluctuations among groups fed different rations in concentrations of Hb, RBC's, Hct, WBC's, total protein, albumin, urea, creatinine, glucose and calcium. On the other hand, the highest values of lymphocytes $\%$ and globulin were recorded with $\mathrm{G}_{2}$ (55.0 and 3.30, respectively) and lowest values were detected with $\mathrm{G}_{1}$ 
( 51.67 and 3.0, respectively) and the differences were significant. Meanwhile, both $\mathrm{MCHC} \%$ and platelets was also higher ( 33.20 and 860, respectively) with $G_{2}$ than other groups but without significance. Serum cholesterol concentration showed some fluctuation among groups, ranging from 59.33 ( in $\mathrm{G}_{1}$ ) to 63.67 ( in $\mathrm{G}_{4}$ ) as shown in Table 5. Both AST and ALT concentrations were higher with $\mathrm{G}_{1}$ ( 87.0 and 21.67 , respectively) compared with the other groups and the differences were significant in AST concentration only. The obtained values are within the normal range reported by Jain 1986 ( for hematological parameters) and Kaneko (1989) ( for biochemical parameters ) for healthy goats.

On the contrary, phosphorus ( inorganic) was noticed to be less $(P<0.05)$ with rations containing Sesbania seeds $\left(G_{3}, 5.23 ، G_{4}, 5.17 \mathrm{mg} /\right.$ $100 \mathrm{ml})$ compared to the control $\left(\mathrm{G}_{1}, 5.57 \mathrm{mg} / 100 \mathrm{ml}\right)$. Kaneko (1989) cited that the normal physiological range of blood phosphorus (inorganic) is from 5.0 to $7.3 \mathrm{mg} / \mathrm{dl}$.

\section{5- Digestion coefficients and feeding value :}

The obtained data in Table 6 indicated that the digestibility of most nutrients (DM, OM, CF, NFE and EE ) and feeding values ( TDN and DCP) were not significantly different among the tested experimental rations. Meanwhile, the CP digestibility was significantly decreased with $\mathrm{G}_{4}(68.0 \%)$ compared with $\mathrm{G}_{1}$ and $\mathrm{G}_{2}$ ( 72.49 and $72.68 \%$, respectively). This may be attributed to the decrease in some essential amino acids such as cysteine, methionine and threonine in Sesbania seeds as reported by Pugalenthi et al. (2004). Generally the highest value of digestion coefficients of all nutrients and TDN were recorded with $G_{2}$ while, the lowest values were recorded with G4 as shown in Table 6.

6- Growth performance :

Performance of male growing Zaraibi goats in relation to different feeding schemes are presented in Table (7). The obtained results revealed that CFM with partial replacing Sesbania seeds (SS) during the experimental period maintained the same growth rate with slight favor for feeding at the high level only. The daily body gain (DBG) values were 75.72 and $71.82 \mathrm{~g} / \mathrm{h}$ for $\mathrm{G}_{1}$ (control) and $\mathrm{G}_{4}$ (high level of SS) as shown in Table (7). But, the highest values of daily body gain (DBG) was recorded with $G_{2}$, without significant differences. These results were related to the digestion coefficients and feeding value as reported earlier in Table 6.

\section{7- Feed conversion:}

Feed conversion of the experimental diets is shown in Table8. Feed conversion based on DM was better with $\mathrm{G}_{2}(8.51)$ followed by (8.55) then $\mathrm{G}_{4}$ (8.65) and lastly $G_{1}(8.80)$. Similarly, the values of feed conversion expressed as TDN intake/kg gain was better in kids received SS diets (5.81, 5.77 and 5.82 for $\mathrm{G}_{2}, \mathrm{G}_{3}, \mathrm{G}_{4}$, respectively) compared with control $\left(\mathrm{G}_{1}, 5.97\right.$ ). A similar trend was noticed when efficiency of conversion was based on DCP where the best was $G_{2}(0.770)$ while others ranged from 0.772 to 0.780 . The obtained values of feed conversion are within the normal range given by Soliman et al. (1997) and Ahmed et al. (2000) for male Zaraibi goats during 
growing period. In this respect, Ahmed (2003) found that the feed efficiency of Zaraibi kids ( aging 7- 8 months) ranged from 7.31 to $8.92 \mathrm{~kg} \mathrm{DM} / \mathrm{kg}$ gain. 8- Economic efficiency :

Economic efficiency (EE), estimated as price of gained weight divided by cost of feed consumed for that gain, are presented in Table 9. The economic efficiency of feeding Zaraibi kids on different experimental rations show reduction in feeding cost $(1.259,1.185,1.106$ and $1.020 \mathrm{~L}$. E) with increasing Sesbania seeds levels $(0,10,20$ and $30 \%)$ in the diets $\left(G_{1}, G_{2}\right.$, $\mathrm{G}_{3}$ and $\mathrm{G}_{4}$, respectively). Also, using Sesbania seeds in kids diets reduced feed cost / $\mathrm{kg}$ gain (L.E) to $15.36,14.85$ and 14.31 for $\mathrm{G}_{2}, \mathrm{G}_{3}$ and $\mathrm{G}_{4}$, respectively compared with value of 16.63 for control $\left(G_{1}\right)$. Therefore, the economic efficiency was noticeably better $(1.86,2.02,2.09$ and 2.17$)$ as a result to using of Sesbania seeds at level $0.0,10,20$ and $30 \%$ in diets of growing male Zaraibi goats ( kids) as shown in Table 9.

Generally, the economic efficiency was improved by about 9.0, 12.0 and $17.0 \%$ with Sesbania seeds rations ( $G_{2}, G_{3}$, and $G_{4}$, respectively) compared with $\mathrm{G}_{1}$ (control). Accordingly, legumes such as Sesbania seeds constitute an important feedstuff and are an economic source of protein in the diets as reported by Kumar et al. (1991) and Pugalenthi et al. (2004).

\section{CONCLUSION}

Sesbania seeds could be safely, economically and successfully used as a source of protein for feed, to replace up to $30 \%$ of CFM protein in goats rations since it did not have adverse effects on ruminal fermentation parameters, blood constituents, feed utilization efficiency and feeding values of rations compared with control. Further studies are however needed to evaluate the utilization of Sesbania seeds at different levels by some other farm animals during different physiological periods and for longer periods.

Table 1. Chemical analysis of feed ingredients and tested diets.

\begin{tabular}{|c|c|c|c|c|c|c|c|}
\hline \multirow[t]{2}{*}{ Items } & \multicolumn{7}{|c|}{ Composition, \% DM basis } \\
\hline & DM & OM & CF & CP & EE & NFE & ASH \\
\hline Concentrate feed mixture, CFM & 90.5 & 94.10 & 15.73 & 14.00 & 3.40 & 60.97 & 5.90 \\
\hline Sesbania sesban seeds, SS & 92.7 & 96.43 & 7.31 & 31.19 & 5.30 & 52.63 & 3.57 \\
\hline Corn silage, CS & 33.3 & 91.0 & 28.69 & 9.10 & 3.17 & 50.04 & 9.00 \\
\hline \multicolumn{8}{|l|}{ Experimental diets : } \\
\hline $60 \%$ CFM $+40 \%$ CS $\left(\mathrm{G}_{1}\right)$ & 67.60 & 92.85 & 20.85 & 12.27 & 3.30 & 56.43 & 7.15 \\
\hline $55 \%$ CFM + 3\% SS + 42\% CS $\left(\mathrm{G}_{2}\right)$ & 66.55 & 92.70 & 20.90 & 12.50 & 3.35 & 56.12 & 7.13 \\
\hline $50 \%$ CFM + $6 \%$ SS + 44\% CS $\left(\mathrm{G}_{3}\right)$ & 65.45 & 92.89 & 20.93 & 12.73 & 3.41 & 55.82 & 7.11 \\
\hline $45 \%$ CFM + 9\% SS + 46\% CS (G4) & 64.40 & 92.90 & 20.95 & 12.97 & 3.47 & 55.51 & 7.10 \\
\hline
\end{tabular}


Table 2. Average daily feed intake* and water consumption by Zaraibi kids fed the experimental rations.

\begin{tabular}{|c|c|c|c|c|}
\hline \multirow[t]{2}{*}{ Items } & \multicolumn{4}{|c|}{ Groups } \\
\hline & $\mathbf{G}_{1}$ & $\mathbf{G}_{2}$ & $\mathbf{G}_{3}$ & $\mathbf{G}_{4}$ \\
\hline \multicolumn{5}{|l|}{ Daily DM intake, g/h : } \\
\hline CFM & 401 & 360 & 320 & 280 \\
\hline SS & - & 18 & 36 & 54 \\
\hline CS & 265 & 279 & 281 & 287 \\
\hline Total DM intake & 666 & 657 & 637 & 621 \\
\hline DM intake, \%BW & 3.39 & 3.30 & 3.24 & 3.19 \\
\hline DM intake, $\mathrm{g} / \mathrm{kg}^{0.75}$ & 71.31 & 69.74 & 68.27 & 66.99 \\
\hline \begin{tabular}{|c|} 
Roughage : \\
concentrate $(\mathrm{R} / \mathrm{C})$ ratio
\end{tabular} & $40: 60$ & $42: 58$ & $44: 56$ & $46: 54$ \\
\hline \multicolumn{5}{|l|}{ Water consumption : } \\
\hline $\mathrm{L} / \mathrm{h} / \mathrm{d}$ & 2.07 & 2.11 & 2.13 & 2.09 \\
\hline $\mathrm{ml} / \mathrm{kg} \mathrm{BW}$ & 105 & 106 & 108 & 107 \\
\hline $\mathrm{ml} / \mathrm{kg}^{0.75}$ & 222 & 224 & 228 & 225 \\
\hline $\mathrm{ml} / \mathrm{g}$ DM intake & 3.11 & 3.21 & 3.34 & 3.36 \\
\hline
\end{tabular}

${ }^{*}$ Group feeding

Table (3):Effect of the experimental rations on ruminal $\mathrm{pH}$ value, ammonia-N concentrations and microbial protein content of Zaraibi kids.

\begin{tabular}{|c|c|c|c|c|c|}
\hline \multirow[t]{2}{*}{ Items } & \multirow[t]{2}{*}{ Hours } & \multicolumn{4}{|c|}{ Groups } \\
\hline & & $\mathbf{G}_{1}$ & $\mathbf{G}_{2}$ & $\mathrm{G}_{3}$ & $\mathbf{G}_{4}$ \\
\hline \multirow[t]{3}{*}{$\mathrm{pH}$ values } & 0 & $6.93 \pm 0.03$ & $7.00 \pm 0.03$ & $6.97 \pm 0.07$ & $7.03 \pm 0.12$ \\
\hline & 3 & $6.53 \pm 0.04$ & $6.57 \pm 0.03$ & $6.55 \pm 0.09$ & $6.53 \pm 0.06$ \\
\hline & 6 & $6.72 \pm 0.06$ & $6.63 \pm 0.05$ & $6.68 \pm 0.04$ & $6.65 \pm 0.08$ \\
\hline \multirow{3}{*}{$\begin{array}{l}\mathrm{NH}_{3}-\mathrm{N} \\
(\mathrm{mg} / 100 \mathrm{ml})\end{array}$} & 0 & $17.17 \pm 0.34$ & $16.93 \pm 0.27$ & $17.0 \pm 0.31$ & $17.27 \pm 0.29$ \\
\hline & 3 & $23.20 \pm 0.40$ & $22.20 \pm 0.20$ & $22.60 \pm 0.53$ & $23.10 \pm .0 .4$ \\
\hline & 6 & $21.27 \pm 0.44$ & $20.87 \pm 0.47$ & $21.03 \pm 0.39$ & $21.13 \pm 0.35$ \\
\hline \multirow{3}{*}{$\begin{array}{l}\text { Microbial } \\
\text { protein } \\
(\mathrm{g} / 100 \mathrm{ml})\end{array}$} & 0 & $0.330 \pm 0.001$ & $0.337 \pm 0.009$ & $0.327 \pm 0.007$ & $0.333 \pm 0.010$ \\
\hline & 3 & $0.553 \pm 0.007^{\mathrm{ab}}$ & $0.563 \pm 0.007^{a}$ & $0.553 \pm 0.009^{a b}$ & $0.527 \pm 0.007^{b}$ \\
\hline & 6 & $0.493 \pm 0.009^{a b}$ & $0.507 \pm 0.009^{a}$ & $0.497 \pm 0.010^{a b}$ & $0.467 \pm 0.007^{b}$ \\
\hline
\end{tabular}

Means in the same row with different superscripts differ significantly at $P<0.05$. 
Table (4) : Effect of feeding experimental rations on ruminal total volatile fatty acids (VFA's) and fraction of VFA's $\%$.

\begin{tabular}{|c|c|c|c|c|c|}
\hline \multirow[t]{2}{*}{ Items } & \multirow[t]{2}{*}{ Hours } & \multicolumn{4}{|c|}{ Groups } \\
\hline & & $\mathbf{G}_{1}$ & $\mathbf{G}_{2}$ & $\mathbf{G}_{3}$ & $\mathbf{G}_{4}$ \\
\hline \multirow{3}{*}{$\begin{array}{l}\text { Total VFA's } \\
(\mathrm{m} \mathrm{Eq} \\
/ 100 \mathrm{ml})\end{array}$} & 0 & $9.03 \pm 0.27$ & $9.17 \pm 0.24$ & $8.77 \pm 0.27$ & $8.87 \pm 0.32$ \\
\hline & 3 & $11.27 \pm 0.19 \mathrm{ab}$ & $11.70 \pm 0.12^{a}$ & $11.30 \pm 0.10^{a b}$ & $11.13 \pm 0.09^{b}$ \\
\hline & 6 & $10.23 \pm 0.12^{a b}$ & $10.57 \pm 0.15^{a}$ & $10.23 \pm 0.09 \mathrm{ab}$ & $10.13 \pm 0.03^{b}$ \\
\hline \multicolumn{6}{|c|}{ Ruminal VFA's \% : } \\
\hline Acetic & \multirow[t]{6}{*}{3} & $48.0 \pm 0.73$ & $49.03 \pm 1.16$ & $48.30 \pm 0.91$ & $47.67 \pm 0.77$ \\
\hline Propionic & & $26.2 \pm 0.47^{\mathrm{ab}}$ & $27.57 \pm 0.34^{a}$ & $26.27 \pm 0.44^{a b}$ & $25.23 \pm 0.19^{b}$ \\
\hline Butyric & & $16.93 \pm 0.35^{\mathrm{ab}}$ & $16.10 \pm 0.38^{b}$ & $17.07 \pm 0.15^{\mathrm{ab}}$ & $18.20 \pm 0.42^{b}$ \\
\hline Valeric & & $3.17 \pm 0.09$ & $2.57 \pm 0.23$ & $2.90 \pm 0.35$ & $3.20 \pm 0.29$ \\
\hline Isobutyric & & $3.10 \pm 0.06$ & $2.50 \pm 0.45$ & $2.90 \pm 0.38$ & $3.13 \pm 0.41$ \\
\hline Isovaleric & & $2.60 \pm 0.21$ & $2.23 \pm 0.22$ & $2.57 \pm 0.35$ & $2.57 \pm 0.30$ \\
\hline
\end{tabular}

Means in the same row with different superscripts differ significantly at $P<0.05$.

Table 5 : Blood profile of male Zaraibi goats as affected by different experimental rations

\begin{tabular}{|c|c|c|c|c|}
\hline \multirow{2}{*}{ Items } & \multicolumn{4}{|c|}{ Groups } \\
\hline & $\mathrm{G}_{1}$ & $\mathrm{G}_{2}$ & $\mathbf{G}_{3}$ & $\mathbf{G}_{4}$ \\
\hline Hemoglobin $(\mathrm{Hb}), \mathrm{g} / \mathrm{dl}$ & $10.53 \pm 0.09$ & $10.67 \pm 0.19$ & $10.43 \pm 0.19$ & $10.50 \pm 0.21$ \\
\hline Hematocrit (Hct), \% & $33.47 \pm 0.84$ & $32.40 \pm 0.64$ & $32.37 \pm 0.48$ & $33.23 \pm 0.48$ \\
\hline Red blood cell (RBC's) $\times 10^{6} / \mathrm{ul}$ & $11.90 \pm 0.35$ & $12.17 \pm 0.19$ & $11.93 \pm 0.13$ & $12.13 \pm 0.32$ \\
\hline $\begin{array}{l}\text { Mean cell hemoglobin conc. } \\
(\mathrm{MCHC}), \%\end{array}$ & $31.50 \pm 0.75$ & $32.90 \pm 0.40$ & $32.23 \pm 0.22$ & $31.60 \pm 0.25$ \\
\hline Platelets $\left(\times 10^{3} / \mathrm{ul}\right)$ & $831 \pm 28.88$ & $860 \pm 24.66$ & $813 \pm 21.86$ & $840 \pm 35.35$ \\
\hline $\begin{array}{l}\text { White blood cells (WBC's) } \\
x 10^{3} / \mathrm{ul}\end{array}$ & $16.03 \pm 0.79$ & $16.40 \pm 0.55$ & $15.77 \pm 0.95$ & $15.67 \pm 0.95$ \\
\hline Nutrophils, \% & $40.33 \pm 1.76$ & $38.33 \pm 2.33$ & $41.67 \pm 1.76$ & $39.00 \pm 1.73$ \\
\hline Lymphocytes,\% & $51.67 \pm 1.76^{b}$ & $55.00 \pm 4.04^{a}$ & $52.67 \pm 1.45^{\mathrm{ab}}$ & $53.33 \pm 1.76^{\mathrm{ab}}$ \\
\hline Monocytes,\% & $4.00 \pm 0.58$ & $3.33 \pm 3.33$ & $2.67 \pm 0.88$ & $3.67 \pm 0.33$ \\
\hline Eosoinophils, \% & $2.00 \pm 0.58$ & $2.00 \pm 0.58$ & $1.67 \pm 0.33$ & $2.33 \pm 0.33$ \\
\hline Basophiles, \% & $1.67 \pm 0.33$ & $1.33 \pm 0.33$ & $1.33 \pm 0.33$ & $1.67 \pm 0.33$ \\
\hline Total protein, g/dl & $6.50 \pm 0.12$ & $6.67 \pm 0.12$ & $6.57 \pm 0.07$ & $6.43 \pm 0.09$ \\
\hline Albumin, $\mathrm{g} / \mathrm{dl}$ & $3.50 \pm 0.10$ & $3.37 \pm 0.09$ & $3.30 \pm 0.06$ & $3.27 \pm 0.07$ \\
\hline Globulin, g/dl & $3.0 \pm 0.15^{b}$ & $3.30 \pm 0.06^{a}$ & $3.27 \pm 0.03^{\mathrm{ab}}$ & $3.17 \pm 0.03^{a b}$ \\
\hline Urea, mg/dl & $49.67 \pm 1.45$ & $50.33 \pm 1.45$ & $48.00 \pm 1.53$ & $46.67 \pm 2.33$ \\
\hline Creatinine, $\mathrm{mg} / \mathrm{dl}$ & $0.87 \pm 0.03$ & $0.90 \pm 0.06$ & $0.77 \pm 0.09$ & $0.83 \pm 0.09$ \\
\hline Glucose, mg/dl & $65.33 \pm 1.45$ & $66.33 \pm 1.45$ & $67.00 \pm 1.00$ & $66.00 \pm 1.15$ \\
\hline Cholesterol, $\mathrm{mg} / \mathrm{dl}$ & $59.33 \pm 4.33$ & $57.00 \pm 1.15$ & $60.00 \pm 2.08$ & $63.67 \pm 0.88$ \\
\hline AST, ul & $86.67 \pm 2.19^{a}$ & $83.67 \pm 0.88^{\mathrm{ab}}$ & $81.33 \pm 1.67^{\mathrm{ab}}$ & $80.00 \pm 2.08^{b}$ \\
\hline $\mathrm{ALT}, \mathrm{ul}$ & $21.67 \pm 1.20^{\mathrm{a}}$ & $20.33 \pm 0.88^{\mathrm{ab}}$ & $21.00 \pm 2.08^{\mathrm{ab}}$ & $19.93 \pm 0.67^{b}$ \\
\hline Calcium, mg/dl & $10.60 \pm 0.51$ & $10.73 \pm 0.42$ & $10.53 \pm 0.37$ & $10.50 \pm 0.45$ \\
\hline Phosphorus (inorganic) mg/dl & $5.57 \pm 0.23^{a}$ & $5.40 \pm 0.15^{\mathrm{ab}}$ & $5.23 \pm 0.21^{\mathrm{b}}$ & $5.17 \pm 0.05^{b}$ \\
\hline
\end{tabular}


Table (6):Digestion coefficients and feeding values of experimental rations fed to male Zaraibi goats.

\begin{tabular}{|c|c|c|c|c|}
\hline \multirow{2}{*}{ Items } & \multicolumn{4}{|c|}{ Groups } \\
\cline { 2 - 5 } & $\mathbf{G}_{1}$ & $\mathbf{G}_{\mathbf{2}}$ & $\mathbf{G}_{\mathbf{3}}$ & $\mathbf{G}_{4}$ \\
\hline \multicolumn{1}{|c|}{ Digestion coefficients $, \%:$} \\
\hline DM & $66.52 \pm 0.69$ & $67.17 \pm 0.73$ & $66.09 \pm 0.59$ & $65.70 \pm 1.11$ \\
\hline OM & $69.28 \pm 0.58$ & $70.02 \pm 0.66$ & $68.87 \pm 0.44$ & $68.64 \pm 0.92$ \\
\hline CF & $61.92 \pm 0.91$ & $62.20 \pm 0.48$ & $61.25 \pm 0.69$ & $60.83 \pm 1.37$ \\
\hline CP & $72.49 \pm 1.05^{\mathrm{a}}$ & $72.68 \pm 0.19^{\mathrm{a}}$ & $70.21 \pm 0.19^{\mathrm{ab}}$ & $68.0 \pm 0.46^{\mathrm{b}}$ \\
\hline EE & $80.09 \pm 0.35$ & $80.72 \pm 0.32$ & $79.97 \pm 0.52$ & $80.29 \pm 0.37$ \\
\hline NFE & $70.79 \pm 0.45$ & $71.67 \pm 0.92$ & $70.93 \pm 0.42$ & $70.83 \pm 1.08$ \\
\hline Feeding values $: \%$ & 67.50 \\
\hline TDN & $67.88 \pm 0.56$ & $68.40 \pm 0.62$ & $67.48 \pm 0.43$ & $67.27 \pm 0.87$ \\
\hline DCP & $8.78 \pm 0.12$ & $9.05 \pm 0.02$ & $9.03 \pm 0.02$ & $9.02 \pm 0.06$ \\
\hline
\end{tabular}

Means in the same row with different superscripts differ significantly at $P<0.05$.

Table (7) : Growth performance of Zaraibi kids fed the experimental rations.

\begin{tabular}{|l|c|c|c|c|}
\hline \multirow{2}{*}{ Items } & \multicolumn{4}{c|}{ Groups } \\
\cline { 2 - 5 } & $\mathbf{G}_{\mathbf{1}}$ & $\mathbf{G}_{\mathbf{2}}$ & $\mathbf{G}_{\mathbf{3}}$ & $\mathbf{G}_{\mathbf{4}}$ \\
\hline No of kids & 5 & 5 & 5 & 5 \\
\hline Feeding period, weeks & 14 & 14 & 14 & 14 \\
\hline Initial weight, $\mathrm{kg}$ & $15.96 \pm 0.33$ & $16.12 \pm 0.31$ & $16.00 \pm 0.33$ & $15.94 \pm 0.31$ \\
\hline Final weight, $\mathrm{kg}$ & $23.38 \pm 0.32$ & $23.68 \pm 0.36$ & $23.30 \pm 0.27$ & $22.98 \pm 0.37$ \\
\hline Total body gain, $\mathrm{kg}$ & $7.42 \pm 0.14$ & $7.56 \pm 0.12$ & $7.30 \pm 0.15$ & $7.04 \pm 0.16$ \\
\hline Daily body gain, $\mathrm{g}$ & $75.72 \pm 1.46$ & $77.16 \pm 1.25$ & $74.50 \pm 1.51$ & $71.82 \pm 1.68$ \\
\hline
\end{tabular}

Table (8): Feed utilization efficiency by Zaraibi kids as affected by the experimental rations.

\begin{tabular}{|c|c|c|c|c|}
\hline \multirow[t]{2}{*}{ Items } & \multicolumn{4}{|c|}{ Groups } \\
\hline & $\mathbf{G}_{1}$ & $\mathbf{G}_{2}$ & $\mathbf{G}_{3}$ & $\mathbf{G}_{4}$ \\
\hline Average daily gain, $\mathrm{g}$ & 75.72 & 77.16 & 74.50 & 71.82 \\
\hline \multicolumn{5}{|c|}{ Average daily DM intake ${ }^{\star}, \mathrm{g} / \mathrm{h}:$} \\
\hline From CFM & 401 & 360 & 320 & 280 \\
\hline From SS & - & 18 & 36 & 54 \\
\hline From CS & 265 & 279 & 281 & 287 \\
\hline Total DM intake, $\mathrm{g} / \mathrm{h}$ & 666 & 657 & 637 & 621 \\
\hline TDN intake, $\mathrm{g} / \mathrm{h}$ & 452 & 448 & 430 & 418 \\
\hline DCP intake, $\mathrm{g} / \mathrm{h}$ & 58.47 & 59.45 & 57.52 & 56.01 \\
\hline \multicolumn{5}{|l|}{ Feed utilization efficiency : } \\
\hline Kg DM / Kg gain & 8.80 & 8.51 & 8.55 & 8.65 \\
\hline Kg TDN / Kg gain & 5.97 & 5.81 & 5.77 & 5.82 \\
\hline $\mathrm{Kg}$ DCP / Kg gain & 0.772 & 0.770 & 0.772 & 0.780 \\
\hline
\end{tabular}


Table (9) : Economic efficiency of Zaraibi kids fed different experimental diets.

\begin{tabular}{|l|c|c|c|c|}
\hline \multirow{2}{*}{ Items } & \multicolumn{4}{|c|}{ Groups } \\
\cline { 2 - 5 } & $\mathbf{G}_{\mathbf{1}}$ & $\mathbf{G}_{\mathbf{2}}$ & $\mathbf{G}_{\mathbf{3}}$ & $\mathbf{G}_{\mathbf{4}}$ \\
\hline \multicolumn{4}{|c|}{} & \multicolumn{4}{|c|}{} & 309 \\
\hline Daily feed intake (g/h) as fed: & 443 & 398 & 354 & 58.3 \\
\hline From CFM & - & 19.4 & 38.8 & 862 \\
\hline From SS & 796 & 838 & 844 & 1.028 \\
\hline $\begin{array}{l}\text { Cost of cons CS } \\
\text { LE/h. }\end{array}$ & 1.259 & 1.185 & 1.106 & 2.226 \\
\hline Price of weight gain, LE/h & 2.347 & 2.392 & 2.310 & 14.31 \\
\hline Feed cost/ kg gain, LE & 16.63 & 15.36 & 14.85 & 2.17 \\
\hline Economic efficiency, \% & 1.86 & 2.02 & 2.09 & \\
\hline
\end{tabular}

\section{REFERENCES}

A.O.A.C. (1995). Official Methods of Analysis (16th Edit). Association of Official Analytical Chemists, Washington, D.C., USA.

Abdel-Rahman, Km, A. A. Kandil, S. El-Khasshab and S. Al-Deeb (1995). Chimical and nutritional studies on some forage shrubs adapted in arid region. J. Agric. Sci. Mansoura Univ. 20(8) 3669- 3645.

Ahmed (2003). The Economic marcting weight of male Zaraibi goats. Egyptian J. Nutrition and Feeds, 6 ( special Issue) : 1311- 1324.

Ahmed, M.E., E.I. Shehata and A.M. Abdelhamid (2000). Growth performance of male kids according to different feeding levels, concentrate to roughage ratio and diet inclusion of bentonite. Proc. $3^{\text {rd }}$ all Africa Conf. Anim. Agric. \& $11^{\text {th }}$ Conf. Egyptian Soc. Anim. Prod., Alexandria, 6-9 November, p: 201.

Arekemase S. O., I. Abdulwaliyu, M. A. Dakare, S. Bala, A. S. Ibraheem and O. L. Nkeonye. (2013). Quantitative evaluation of the nutritional constituents of Sesbania sesban seeds and pods. International Journal of Modern Plant \& Animal Sciences, 1(1): 16-27

Conway, E.F.(1957). Micro diffusion Analysis and Volumetric Error. Rev. Ed. Lock Wood, London.

Duncan, D. (1955). Multiple ranges and multiple F-test. Biometrics,11: 1.

FAO/WHO, (1991). Protein quality evaluation. Food and Agricultural Organization of the United Nations, Rome, Italy. P. 66.

Hossain M. A. and Becker K. (2001). Nutritive value and nutritive factors in different verities of Sesbania seeds and their morphological factors. food chem., 73: 421-431.

Ibrahim, F.A., Soliman, E.S, A. A. Abd El-Hamid and M. E. Ahmed. (2012). Growth performance and feed utilization efficiency of Rahmani lambs fed some legume and /or grass silages. Egyptian J. of Sheep and Goats Sciences, 7 (2): 1 - 10 .

Jain, N.C. (1986). Veterinary Hematology. 4thEd., Lea \& Febiger. Philadelphia. 
Kaneko. I.H. (1989). Chemical Biochemistry of Animals. 4th ED. Academic Press, Inc USA.

Kumar, s, Kumar,S, Singh, G K, kumar,R, Bahatia. NK, and Awasthi, CP. (1991). Variation in quality traits of pigon pea Cajanus cajan L. M, ( SP) Varieties. Journal of Food Science and Technology, 28 : 173- 174.

Mohamed, A. I. and Rangappa, M. (1992). Screening soybean ( grain and vegetable) geno type for nutrients and anti nutritional factors. Plant Foods for Human Nutrition. 42:87-96.

NRC (1981).Nutrient Requirements of Domestic Animals. Nutrient Requirements of Goats. National Research Council, Washington, D.C. USA, of Official Analytical Chemists, Washington, D.C., USA.

Pugalenthi, M. V. Vadivel, P. Gurumoorthi and K. Janardhanan (2004). Comparative nutritional evaluation of little known legumes, Tamarindus indica, Erythrima indica and Sesbania bispinosa. Tropical and Sub tropical Agroecosy tems. (4) : 107-123.

Shehata, E.I., M.E. Ahmed, Faten. F. Abou Ammou, A.A. M. Soliman, K.M. Aiad and A.M. Abdel-Gawad (2006). Comparison of feeding reed as hay or silage with feeding berseem hay or maize silage to dairy Zaraibi goats. Egyptian Sheep Goats and Desert Animals Sci., 1(1): 233-247.

Shultz, T.A. and E. Shultz (1970). Estimation of rumen microbial nitrogen by three analytical methods. J. Dairy Sci , 53:781.

Snedecor, G. W. and W. G. Cochran (1982). Statistical Methods. 7th ed. lowa State Unvi. Press, Ames, lowa, USA.

Soliman, A. A., M. E. Ahmed, Faten. F. Abou Ammou, E. I. Shehata, M. K. Abou Elmaged, S. A. Tawfik and M. A. Shebl ( 2010). Impact of some feed additives on Zaraibi goats performance and blood profile fed aflatoxins contaminated diets. American- Eurasian J. Agric. And Erviron Sci.., 7 (1) : 80.

Soliman, E.S, A.E.M. Kinizy, Bahira K. Mohamed and M. El-H. Haggag (1997). Studies on using sesbania and Teosinte forage in feeding of growing Zaraibi goats Egypt. J. Appl. Sci.,12 (5) : 36.

Tawfik, S.A, M.E. Ahmed, E.I. Shehata and O.B. EL-Gazzar (2005). Effect of adding chamomile flowers to aflatoxins contaminated diet on growth performance, rumen parameters and some blood components of growing lamb's .4th Int. Sci. Conf., Mansoura. 251.

Warner, A.C.I. (1964). Production of volatile fatty acids in the rumen, methods of measurements. Nutr. Abst. \& Rev., 34: 339.

Yanez, E, Zacarias, I, Aguayo, M, Vasquez,M and Guzman, E. (1995). Nurtitive value evaluated on rats of new cultivars of common beans ( Phaseolus vulgaris) relased on Chile. Plant foods for human nutrition. $47: 301-307$.

Zeid, A.M., E .I. Shehata, M.E. Ahmed and A.M. Abdel-Gawad (2009). Growth performance of male Zaraibi goats fed teosinte forage in rations differing in roughage : concentrate ratio. J. Agric. Sci. Mansoura univ., 34 (11): 10441. 


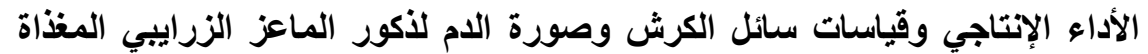

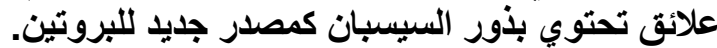

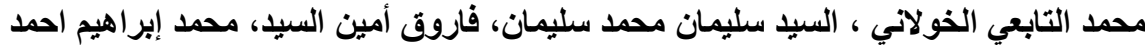

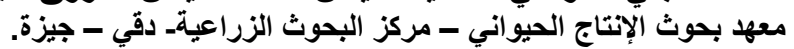

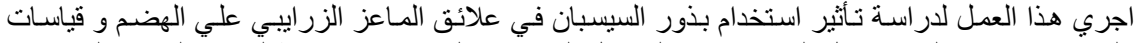

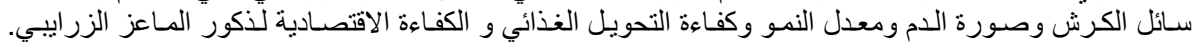

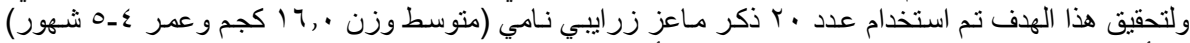

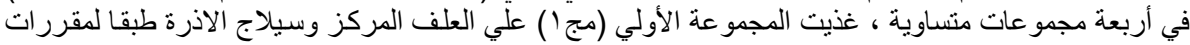
لعام( (919C

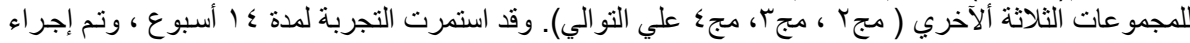

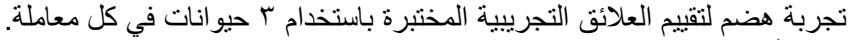

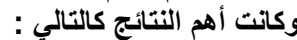

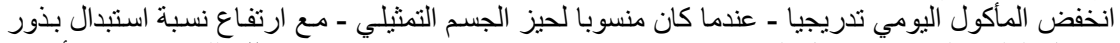

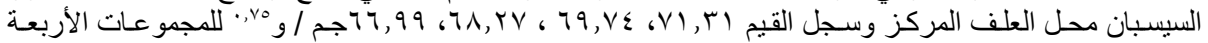

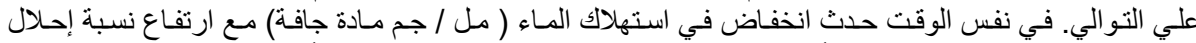

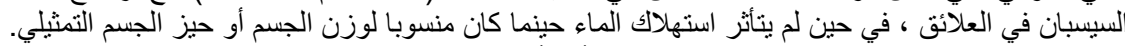

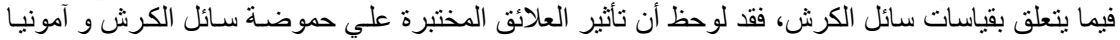

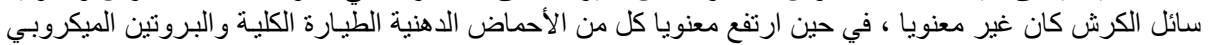

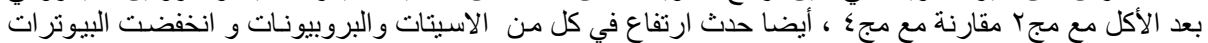

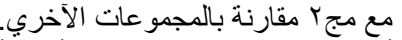

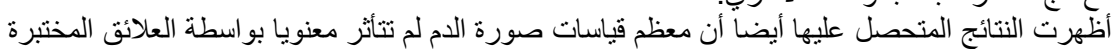

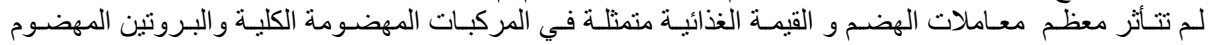

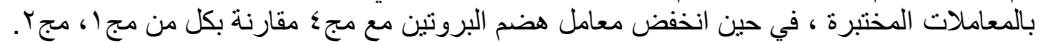

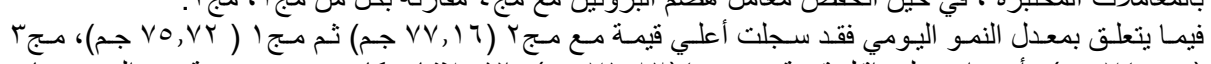

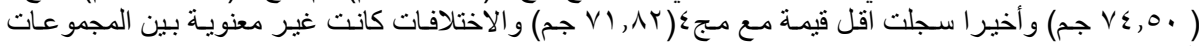
المختبرة . المعان.

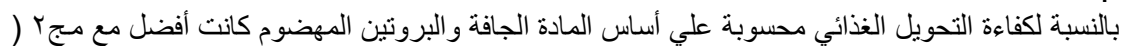

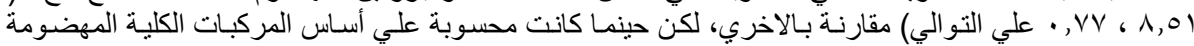

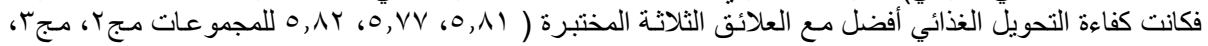

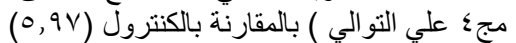

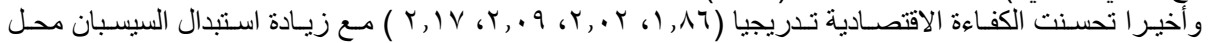

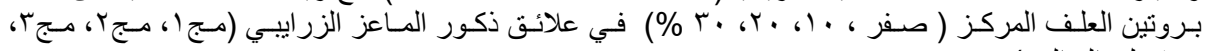

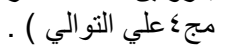

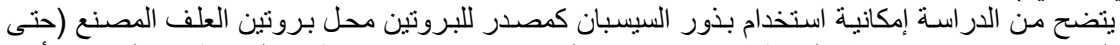

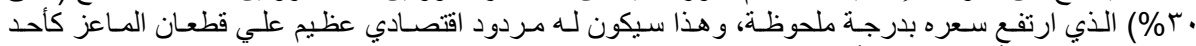

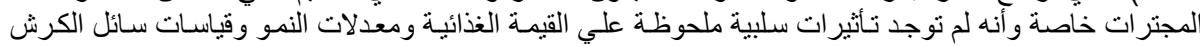

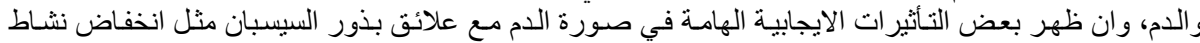

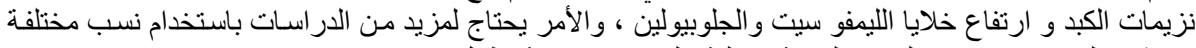

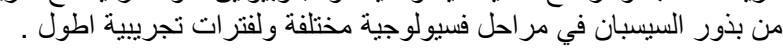

كلية الزراعة - جامعة المنصورة

مركز البحوث الزراعية
قام بتحكيم البحث أ. أد / التمد زكى محرز

أ.د / فتحية ابراهيم عبد العظيم 